\title{
Fifty years of change in the lower tree line in an arid coniferous forest in the Qilian Mountains, northwestern China
}

\section{Shu Fang}

Shangluo University https://orcid.org/0000-0001-5221-9803

Zhibin He ( $\nabla$ hzbmail@lzb.ac.cn )

Northwest Institute of Eco-Environment and Resources, Chinese Academy of Sciences

\section{Research}

Keywords: arid mountains, lower tree line, vegetation landscape, climate change

Posted Date: April 5th, 2021

DOI: https://doi.org/10.21203/rs.3.rs-346610/v1

License: (c) (i) This work is licensed under a Creative Commons Attribution 4.0 International License.

Read Full License 
1 Fifty years of change in the lower tree line in an arid coniferous forest in the Qilian

2 Mountains, northwestern China

3 Shu Fang 1, Zhibin He 2*

41 College of Urban, Rural Planning and Architectural Engineering, Shangluo University,

5 Shangluo 726000, China

62 Linze Inland River Basin Research Station, Chinese Ecosystem Research Network,

7 Key Laboratory of Eco-hydrology of Inland River Basin, Northwest Institute of Eco-

8 Environment and Resources, Chinese Academy of Sciences, Lanzhou 730000, China;

9 fangs@1zb.ac.cn

10 *Correspondence: hzbmail@1zb.ac.cn; Tel.: +86-136-6930-4220

\section{Abstract}

12 Background: Tree-line areas exhibit significant changes in response to climate change,

13 including upward migration. Lower tree line dynamics are rarely studied, but as unique

14 features in arid and semi-arid areas, they may influence forest distribution. Here, 8

15 lower tree-line plots in Picea crassifolia Kom. (Qinghai spruce) forest in the arid and

16 semi-arid Qilian Mountains of northwestern China were used to determine changes in

17 tree line location, landscape pattern, and relationships with meteorological factors

18 during 1968-2018.

19 Results: The results showed that the lower tree line descended by an average of 9.82

20 m during 1968 to 2018, and exhibited almost no change after 2008. The change in

21 pattern was mainly related to the age of trees in which small trees were dense and 
22 clustered, and large trees became more scattered and evenly distributed. Tree

23 regeneration rates changes in the lower tree line were highly positively correlated with

24 temperature, and also positively related to annual precipitation.

25 Conclusions: In the past 50 years, the lower tree line in arid areas exhibited a

26 downward trend but it is unclear whether the downward trend of the lower tree line will

27 stabilize or even reverse due to the weakening of climate warming degree.

28 Keywords: arid mountains, lower tree line, vegetation landscape, climate change

29 1. Background

Tree lines are apparent vegetation boundaries, commonly defined as the

31 elevational limit of trees greater than $2 \mathrm{~m}$ in height [1-3]. The area extent and pattern

32 of tree lines have important geological and ecological meaning, and changes in tree

33 lines play an important role in the development of mountains and regional ecological

34 changes [4-6]. Over the past century, mountain areas have experienced greater climate

35 warming, increased carbon dioxide concentration, and increased extreme weather

36 events than the global average $[7,8]$. Tree line ecotones are more sensitive to climate

37 change and are therefore ideally suited for climate change monitoring [9-12].

Tree lines are comprised of the upper and lower forest boundaries, and they

39 determine the distribution of forests in mountain regions. However, the lower tree lines

40 generally only appear in arid or semi-arid mountainous areas worldwide $[13,14]$. In the

41 arid and semi-arid mountainous areas along the lower tree line, climate change is more

42 complex than elsewhere [15] and exhibits increases in temperature, decreases in 
precipitation frequency, and increases in extreme rainfall events [16]. More significant climate change and the scarcity of water resources render tree line vegetation in arid areas more fragile and more susceptible to climate change [17].

Although the mountain environment where the lower tree lines are located is more fragile and sensitive, the lower tree lines received little scientific attention [18]. In contrast, much research has been conducted in the upper lines of mountain forest belts, including studies on distribution, formation mechanism, and the response of tree line regional location and landscape pattern to climate change [7, 19-21]. Research on the lower tree line in the arid and semi-arid areas in northwestern China is also relatively scarce [22].

There are lots of studies pay attention to the relationship between the tree line position, pattern and the change due to meteorological factors. It has been determined that the change in the upper tree line is mainly related to temperature, while the change in the lower tree line is limited by precipitation. The formation of the upper tree line is limited by the growing season mean air temperature of 5.5 to $7.0^{\circ} \mathrm{C}$ or a growing season mean soil temperature of $6.7-0.8 \mathrm{C}$ at $10 \mathrm{~cm}$ soil depth $[23,24]$. Further, at lower tree line positions, tree demographic processes are more vulnerable to water stress and balance $[25,26]$. Also, radial growth at lower tree lines appears more closely related to climate change, in particular to precipitation from May to June [13].

We chose Picea crassifolia Kom. forest lower tree line in the arid region of northwestern China to study the response of the lower tree line position and landscape 
64 pattern to climate change. Located in the northwestern arid region of China, forest

65 vegetation of the Qilian Mountains is not only a valuable forest resource, but also have

66 the ecological function of water conservation [27]. Picea crassifolia Kom. forest is the

67 dominant and establishment tree species in the Qilian Mountains, [28]. Under the

68 influence of climate change in recent years, vegetation cover and growth in Qilian

69 Mountains have changed significantly[29] and the cover of the main spruce species,

70 Picea crassifolia Kom., has also increased, and the boundary of the up tree line has

71 been moving up [30]. The researches of Picea crassifolia Kom. mostly focuses on

72 dendroclimatology and pay more attention to the changes in the upper tree line [31-33].

73 A sample survey along an elevational transect can be used to reconstruct

74 deterioration of tree conditions ; it is a powerful tool to investigate the relationships of

75 tree growth and climate change [20]. We selected a typical watershed in the Qilian

76 Mountains to conduct a sample survey of the lower tree line area to determine changes

77 in, if any, over the past 50 years in: (1) the position of Picea crassifolia Kom. forest at

78 the lower tree line, (2) Picea crassifolia Kom. landscape pattern at the lower tree line,

79 and (3) the main meteorological factors affecting the changes in Picea crassifolia Kom.

80 forest at the lower tree line. This research increases the understanding of processes in

81 the lower tree line position and landscape pattern change in arid and semi-arid regions

82 with climate change.

\section{2. Methods}




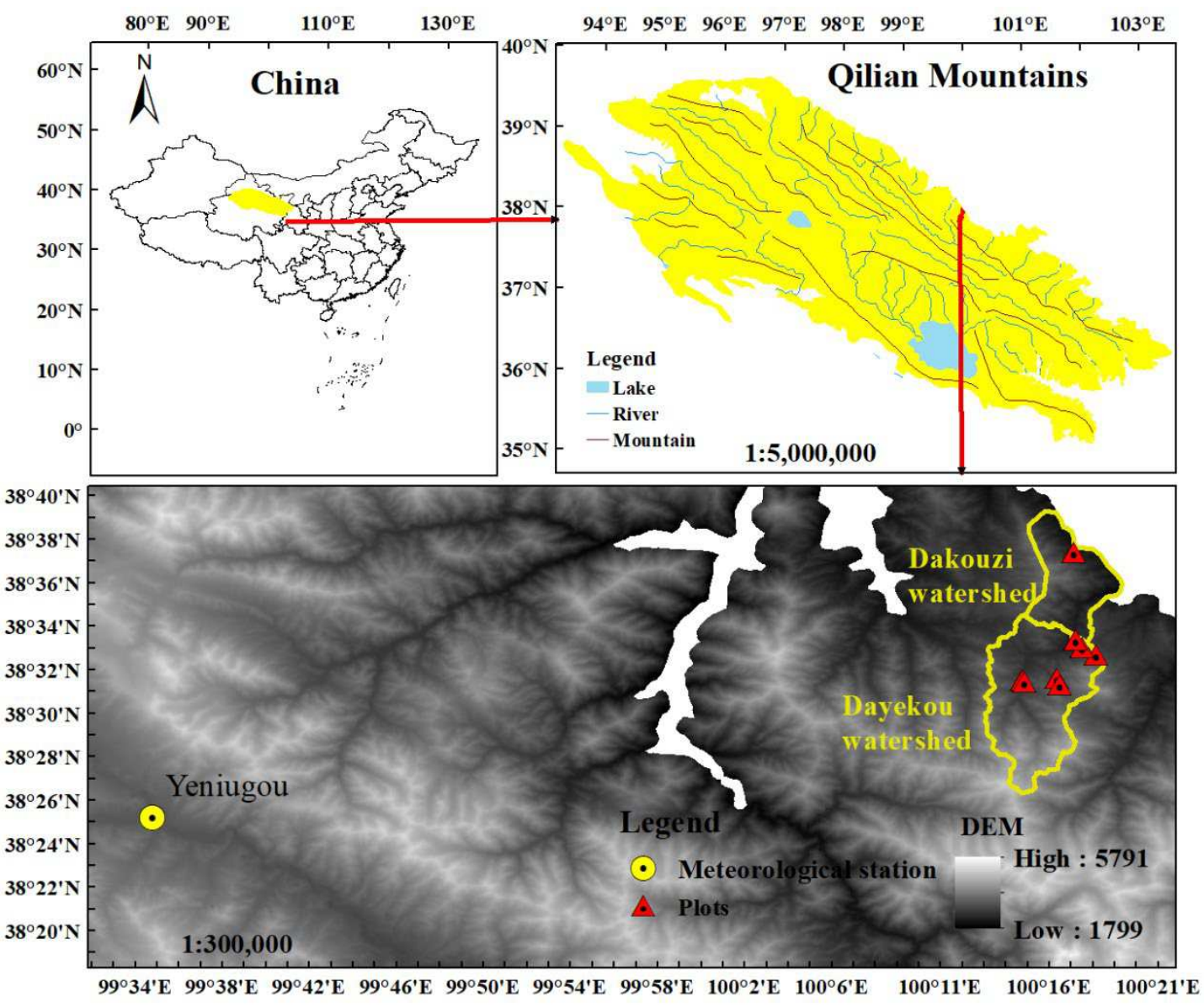

Figure 1. Study Area in the Qilian Mountains of northwestern China. 
101 slope of the area and includes the boundary of the tree line. All trees with height of $<1.3$

106 the tree line $(>2 \mathrm{~m})$, and the measurement height of breast diameter. The area of each

107 plot is $50 \times 30 \mathrm{~m}^{2}$.

108 Table1 Characteristics of the sites, in aspect, 1 for shaded slopes $\left(\mathrm{N}\left(0-22.5^{\circ}, 337.5-\right.\right.$

$\left.\left.109360^{\circ}\right)\right), 2$ for semi-shaded (NE (22.5-67.5 $\left.), \mathrm{E}\left(67.5-112.5^{\circ}\right), \mathrm{NW}\left(292.5-337.5^{\circ}\right)\right)$, and

1103 for partly-sunny slopes (SW $\left(112.5-157.5^{\circ}\right)$, SE $\left(202.5-247.5^{\circ}\right)$, and W $(247.5-$

$$
\left.\left.292.5^{\circ}\right)\right)
$$

\begin{tabular}{ccccccc}
\hline $\begin{array}{c}\text { Plot } \\
\text { Number }\end{array}$ & Latitude & Longitude & $\begin{array}{c}\text { Elevati } \\
\text { on }(\mathrm{m})\end{array}$ & Aspect & $\begin{array}{c}\text { Picea crassifolia } \\
\text { Kom.(number) }\end{array}$ & $\begin{array}{c}\text { Qilian Juniper } \\
\text { (number) }\end{array}$ \\
\hline 1 & $100.29^{\circ} \mathrm{E}$ & $38.62^{\circ} \mathrm{N}$ & 2595 & 2 & 156 & 0 \\
2 & $100.30^{\circ} \mathrm{E}$ & $38.54^{\circ} \mathrm{N}$ & 2980 & 2 & 397 & 10 \\
3 & $100.29^{\circ} \mathrm{E}$ & $38.55^{\circ} \mathrm{N}$ & 2800 & 1 & 282 & 0 \\
4 & $100.27^{\circ} \mathrm{E}$ & $38.53^{\circ} \mathrm{N}$ & 3013 & 2 & 176 & 1 \\
5 & $100.25^{\circ} \mathrm{E}$ & $38.53^{\circ} \mathrm{N}$ & 2852 & 3 & 75 & 68 \\
6 & $100.25^{\circ} \mathrm{E}$ & $38.52^{\circ} \mathrm{N}$ & 2848 & 2 & 112 & 25 \\
7 & $100.27^{\circ} \mathrm{E}$ & $38.52^{\circ} \mathrm{N}$ & 3091 & 1 & 61 & 0 \\
8 & $100.29^{\circ} \mathrm{E}$ & $38.56^{\circ} \mathrm{N}$ & 2673 & 2 & 170 & 1 \\
\hline
\end{tabular}




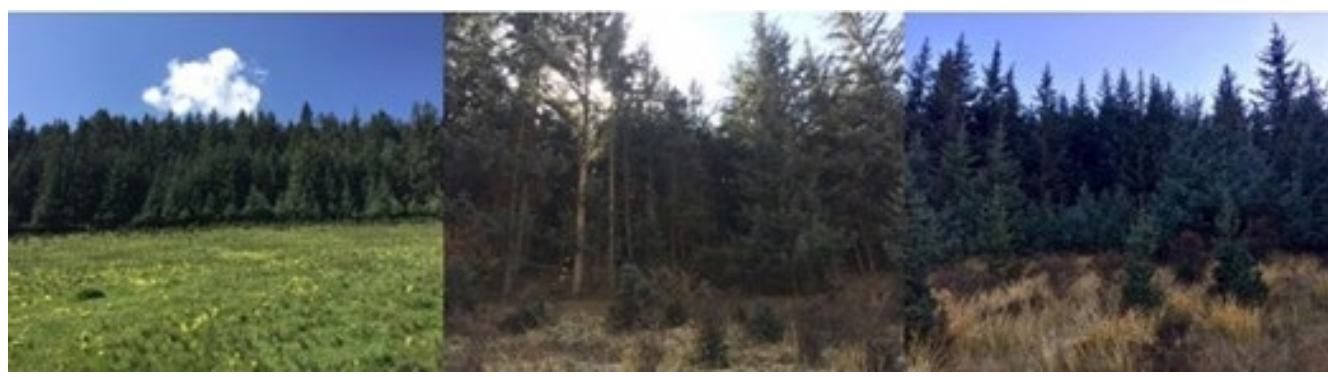

Figure 2. Examples of conditions in sample spots.

115 1) located at a mean distance of $<45 \mathrm{~km}$ and altitude of $3,180 \mathrm{~m}$. We calculated climate

116 variables of average monthly temperature, monthly precipitation, seasonal average

117 temperature, seasonal precipitation, annual average temperature, annual precipitation

118 from 1964-2013 to determine the relationship between Picea crassifolia Kom. lower

119 tree line change and climate. and measured breast diameter (at $1.3 \mathrm{~m}$ ) of 358 trees with a height of $>1 \mathrm{~m}$. Trees in the sample plot cover Picea crassifolia Kom. forests of various ages, and the age of each tree was determined with tree core sampling [35]. Based on the data from the Guantai

128 site, we first calculated the average DBH of each tree age group. Then, we fitted a

129 function between $\mathrm{DBH}$ and the age of the tree. The simulation found that the power 
130 function had the best fit. The formula was $\mathrm{Y}=4.8827 \mathrm{X}^{0.9661}\left(\mathrm{R}^{2}=0.7253, \mathrm{P}<0.001\right)$

131 (Figure 3). Using this simulation formula, we calculated the age of all Picea crassifolia

132 Kom. forests in the sample based on the DBH data of each tree in the sample survey.

133 Then we calculated the age structure of Picea crassifolia Kom. forest in each plot to

134 expresse the results of changes in the relative rates of tree recruitment and mortality

135 over time by a population of live trees [36].

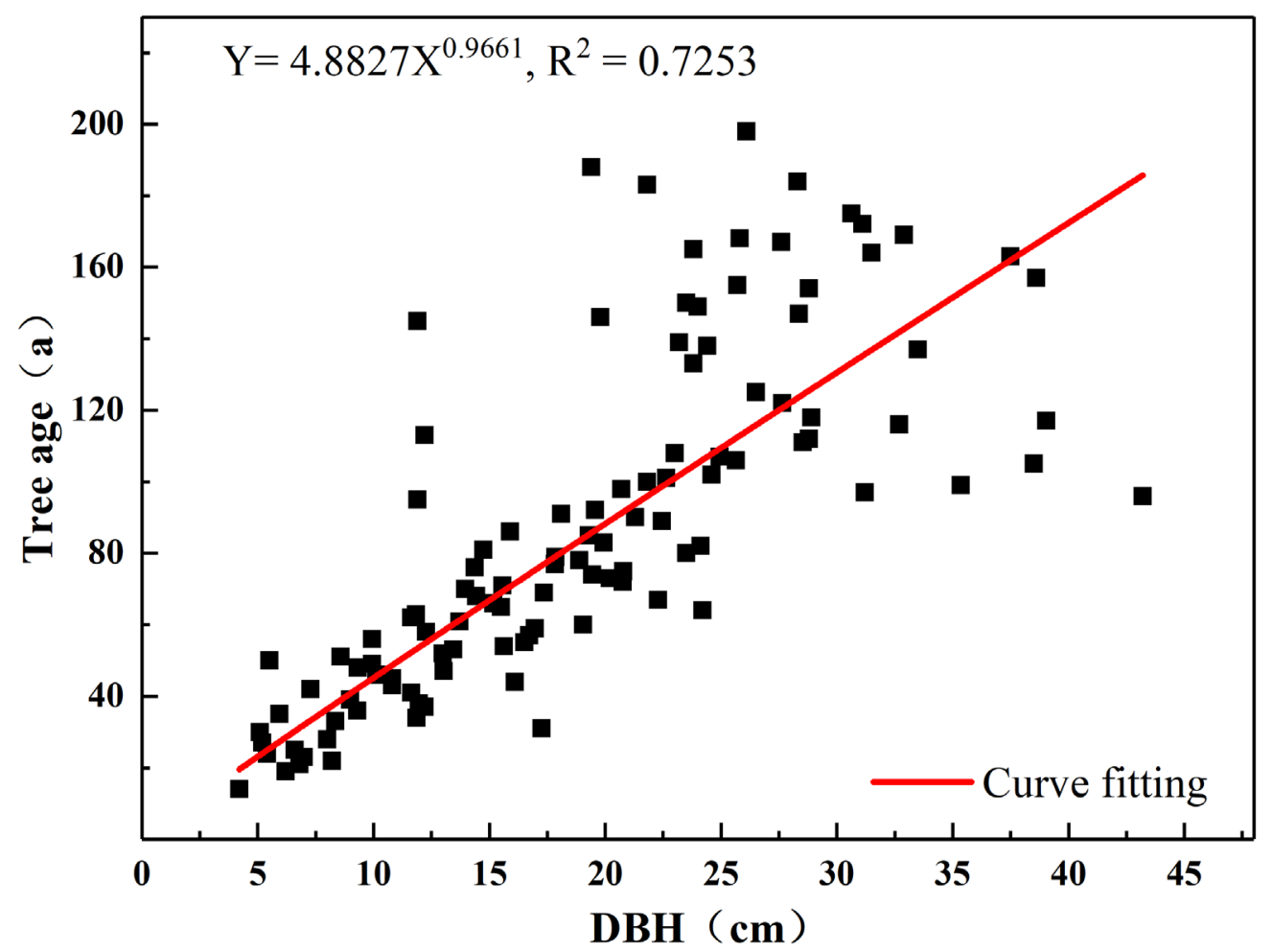

136

Figure 3. Functional relationship between diameter at breast height and age of trees in Guantai sampling.

140 tree line position for an individual slope as the mean elevation of the 20 lowermost $P$.

141 crassifolia trees $>2 \mathrm{~m}$ in height that were alive in a given year [3]; then, using this 142 definition, we determined the elevation ( $\mathrm{y}$ coordinate) of the upper and lower tree line 
144 2018). Then we calculated the average elevation of the lower forest line in different 145 periods.

$\mathrm{K}$ statistic is an average isotropic measure of the type of spatial pattern. The specific

151 calculation method is as follows:

153 following formula:

$$
\mathrm{K}(\mathrm{t})=\lambda^{-1}
$$
estimated by $\mathrm{n} / \mathrm{A}, \mathrm{A}$ is the plot area, and $\mathrm{n}$ is the total number of points (number of

156 individual plants). In practice, the following formula was used to estimate:

$$
\widehat{K}(t)=\left(\frac{A}{n^{2}}\right) \sum_{i=1}^{n} \sum_{j=1}^{n} \frac{1}{W_{i j}} I_{i}\left(u_{i j}\right) \quad(i \neq j)
$$

158 when $u_{-} i j>t$ is, $I_{-} i\left(u_{-} i j\right)=0 ; W_{-} i j$ is the center of point $\mathrm{i}$, and $u_{-} i j$ is the radius. The 


$$
H(t)=\sqrt{\frac{\widehat{K}(t)}{\pi}}
$$

Spatial pattern was obtained with:

$$
L(t)=\widehat{H}(t)=\sqrt{\frac{\widehat{K}(t)}{\pi}}-t
$$

$161 \mathrm{~L}(\mathrm{t})$ was used to represent the pattern of the forest. Where, $\mathrm{L}(\mathrm{t})$ should be equal to

1620 at all scales $t$, when distribution is random. If $\mathrm{L}(\mathrm{t})>0$, the population is distributed in

163 clusters at scale $\mathrm{t}$; if $\mathrm{L}(\mathrm{t})<0$, the population is uniformly distributed at scale $\mathrm{t}$.

164 To test for significance of the deviation of $\mathrm{L}(\mathrm{t})$ from zero, Manly [38] proposed to use the Monte Carlo stochastic simulation method to fit 95\% confidence interval. Using $\mathrm{t}$ as the abscissa and the upper and lower envelope traces as the ordinate. We used the actual distribution data of the population (dot map) to calculate the $\mathrm{L}(\mathrm{t})$ value at different scales. Values within the envelope range indicated random distribution, values

169 above indicated aggregate distribution, and values below indicated even distribution. We analyzed the spatial pattern of trees in each plot using the Ripley's K function

171 and Monte Carlo stochastic simulation method in ADE4 package [39]. The confidence

172 interval was $99 \%, \mathrm{P}<0.01$; the interval selected was $1 \mathrm{~m}$, and the maximum scale was

173 selected to be half of the minimum side length of plot. Plot sides were $15 \mathrm{~m}$.

1742.4 Correlation analysis between tree regeneration and climate change variables

175 We determined the annual regeneration rate of trees from 1968 to 2013 based on 176 the calculated age of trees. The formula was as follows: 


$$
N_{i}=N_{S} \frac{1}{(1-m)^{j}}
$$

Where $N_{i}$ was the number of trees recruited in year i, $N_{S}$ was the number of

178 trees recruited that survived until 2013, m was mortality rate (which we assumed

179 represented a constant value of $4.9 \%$ per year), and $\mathrm{j}$ was the time interval from year $\mathrm{i}$

180 to 2013 . The value of $N_{S}$ was obtained for each tree age class; Ns value of 0 indicated

181 that all of the trees that were recruited in year i $\left(N_{i}\right)$ have died.

182 To study the impact of climate change on tree recruitment in tree line ecotones, we

183 used Pearson's correlation coefficient between tree recruitment rates and values of

184 climate variables in a given year using SPSS 19 [40]. Significance level was $\mathrm{P}=0.01$

185 or $\mathrm{P}=0.05$. If the sample's correlation coefficient is greater than or equal to this critical

186 value, the correlation passes the test

187 3. Results

$188 \quad 3.1$ Basic characteristics of plots

189 We counted the basic information of the plots at the lower tree line (Table 2).

190 Combines with Table 1 we can find that the number of Picea crassifolia Kom. trees on

191 shaded and semi-shaded slopes plots was higher than that on the partly-sunny slope.

192 There were sporadic Qilian junipers on the semi-shaded slope. The number of Qilian

193 junipers on the partly-sunny slope was almost the same as that of Picea crassifolia Kom.

194 Canopy and tree line density at the lower tree line at an altitude below $2600 \mathrm{~m}$ and

195 above $3000 \mathrm{~m}$ were slightly lower than those in other tree line plots. The smaller the 
196 stand density, the larger the average breast diameter and average tree age.

Table 2. Survey characteristics of the sites.

\begin{tabular}{cccc}
\hline Plot Number & $\begin{array}{c}\text { Stand density } \\
\left(\text { number/hm }{ }^{2}\right)\end{array}$ & Average breast diameter (cm) & Average forest age (a) \\
\hline 1 & 1040 & 5.4 & 39 \\
2 & 2647 & 6.0 & 42 \\
3 & 1880 & 9.5 & 46 \\
4 & 1173 & 8.5 & 44 \\
5 & 500 & 18.0 & 69 \\
6 & 747 & 13.2 & 59 \\
7 & 407 & 16.3 & 66 \\
8 & 1133 & 12.3 & 51 \\
\hline
\end{tabular}

198

The age structure of trees at the lower tree line is similar age structure at all three

199 sampling sites. The younger trees that have been recruited since 1980 reached $68 \%$ of

200 the current population; and reached 78\% since 1960. (Figure 4).

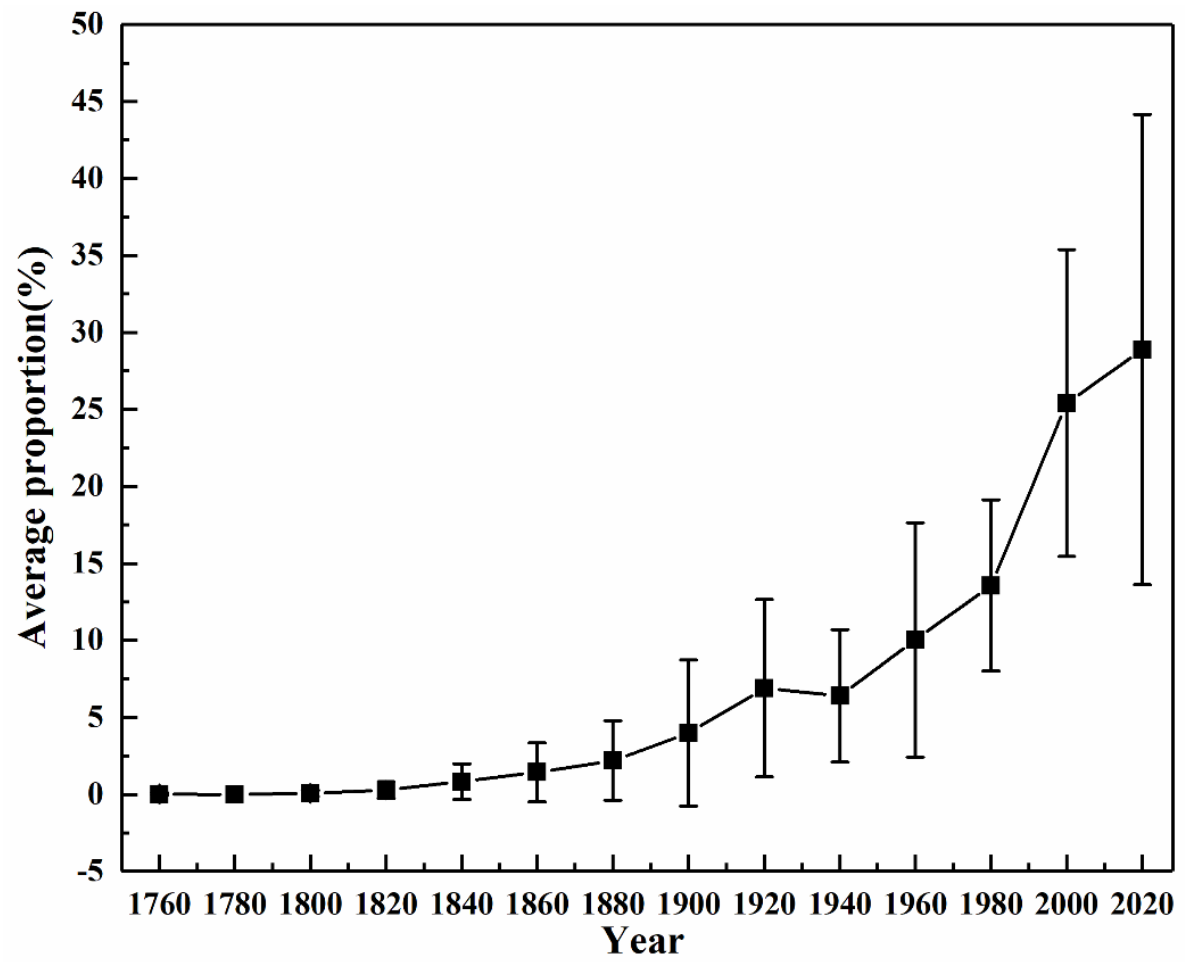

202 Figure 4. The age structure of the tree populations at the in the tree line ecotones plots at the lower tree line. 
207 descent has been decreasing from 1978 to 2018 . The tree line for plot 2, 3, and 4 208 descended by 23.55, 18.85, and $10.20 \mathrm{~m}$, respectively, between 1968 and 2018. In plot 2093 , the rate of tree line descent first decreased, and then increased slightly from 1998 to 210 2008; while in plot 2 and 4, it showed a slight upward trend from 1968 to 1998, and 211 then fell sharply.
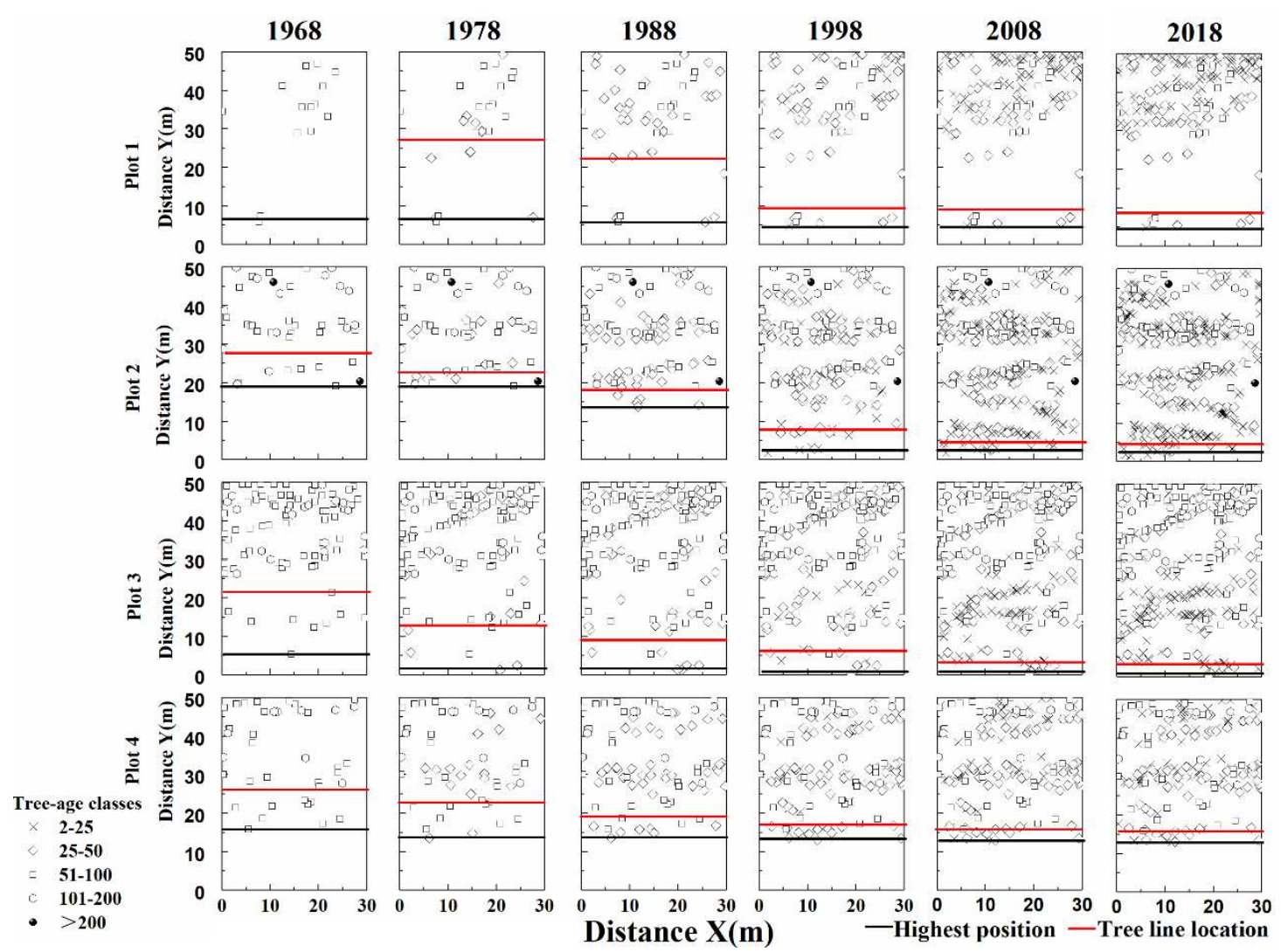

213 Figure 5a. Changes in position of the lower tree line (1) (Distance $Y(m)$ is the distance along the slope direction and Distance $\mathrm{X}(\mathrm{m})$ is the distance spline perpendicular to the slope direction.) 
217 5b), moving down by 3.54, 2.58, 6.36, and 5.41m, respectively, between 1968 and 2018 .

218 The decline rate in plots 5, 7, and 8 first decreased and increased during 1988-1998,

219 and then rapidly decreased. The descent rate of the tree line in plot 6 slowed in 1998-

2202008 , and then stabilized.
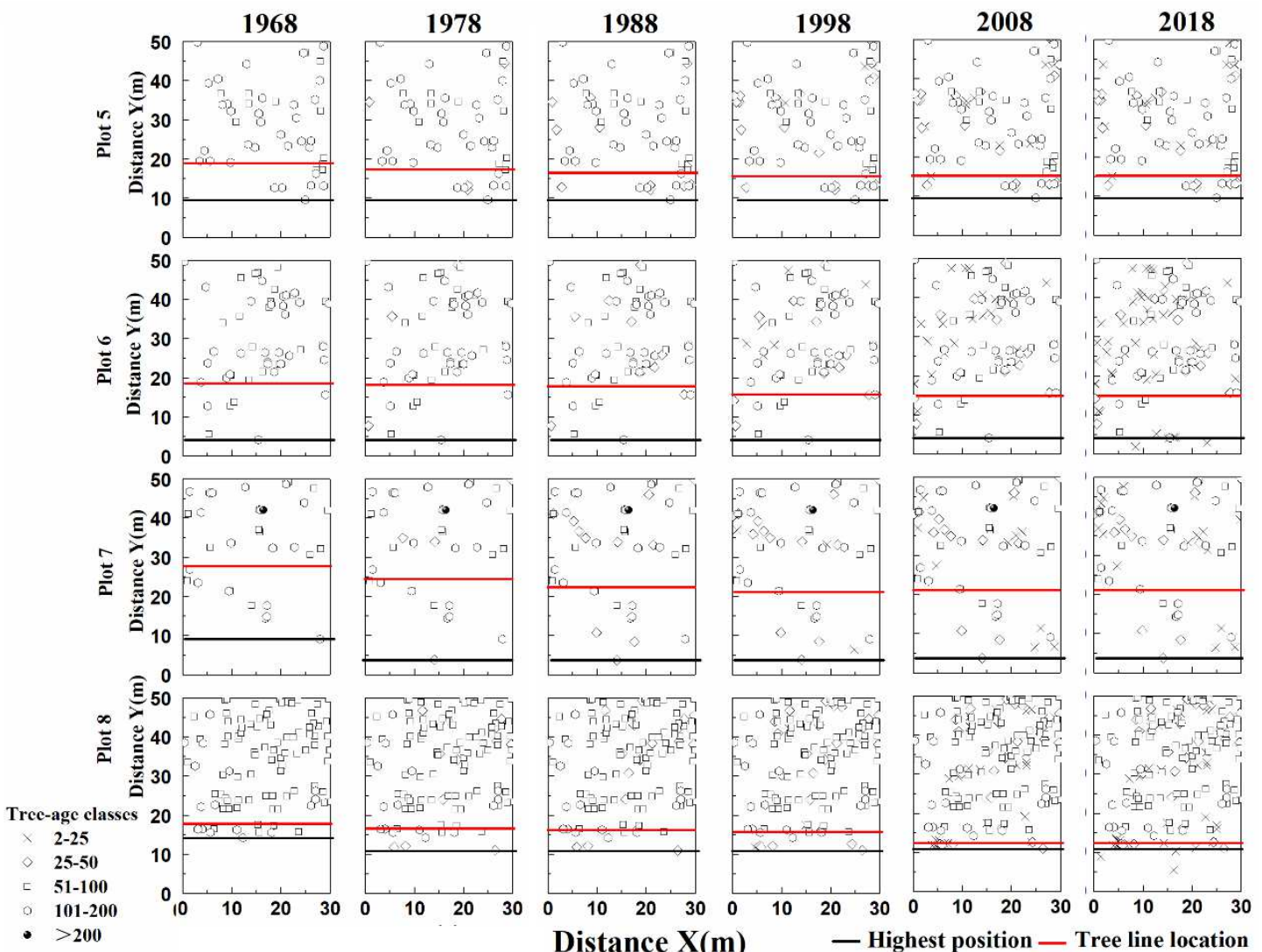

Distance $\mathbf{X}(\mathbf{m})$

Figure 5b. Changes in position of the lower tree line (2)

The lower tree line has moved down by an average of $9.82 \mathrm{~m}$ in the last 50 years

224 (Table 4). The decline was greatest in 1988-1998. Although the descent continued after

225 1998, the extent was much smaller and the lower tree line remained almost unchanged

226 from 2008 to 2018. 

elevation of the lower tree line.

\begin{tabular}{ccccccc}
\hline Year & $1968-1977$ & $1978-1987$ & $1988-1997$ & $1998-2007$ & $2008-2018$ & $\begin{array}{c}\text { Total for } \\
1968-2018\end{array}$ \\
\hline Mean $(\mathrm{m})$ & 2.98 & 2.83 & 3.05 & 1.34 & 0.00 & 9.82 \\
Standard Deviation(m2) & 2.44 & 1.85 & 3.64 & 1.43 & 0.00 & 7.53 \\
\hline
\end{tabular}

2313.3 Dynamics of the spatial pattern at the lower tree line

232 Changes in spatial pattern at the lower tree line were determined with point-pattern

233 analysis at different scales and in different years (Figure 6). In our analysis of spatial

234 point patterns, we found that not all plots exhibited uniform distribution at all scales,

235 and there was a trend to shift from random to cluster distribution at the lower tree line.

236 Plots with older average tree ages were more randomly distributed at all scales. We also

237 found that trees of different ages clustered together and clear boundaries occurred.

238 Small trees were dense and clustered, and large trees became more scattered and evenly

239 distributed (Figure 7). 

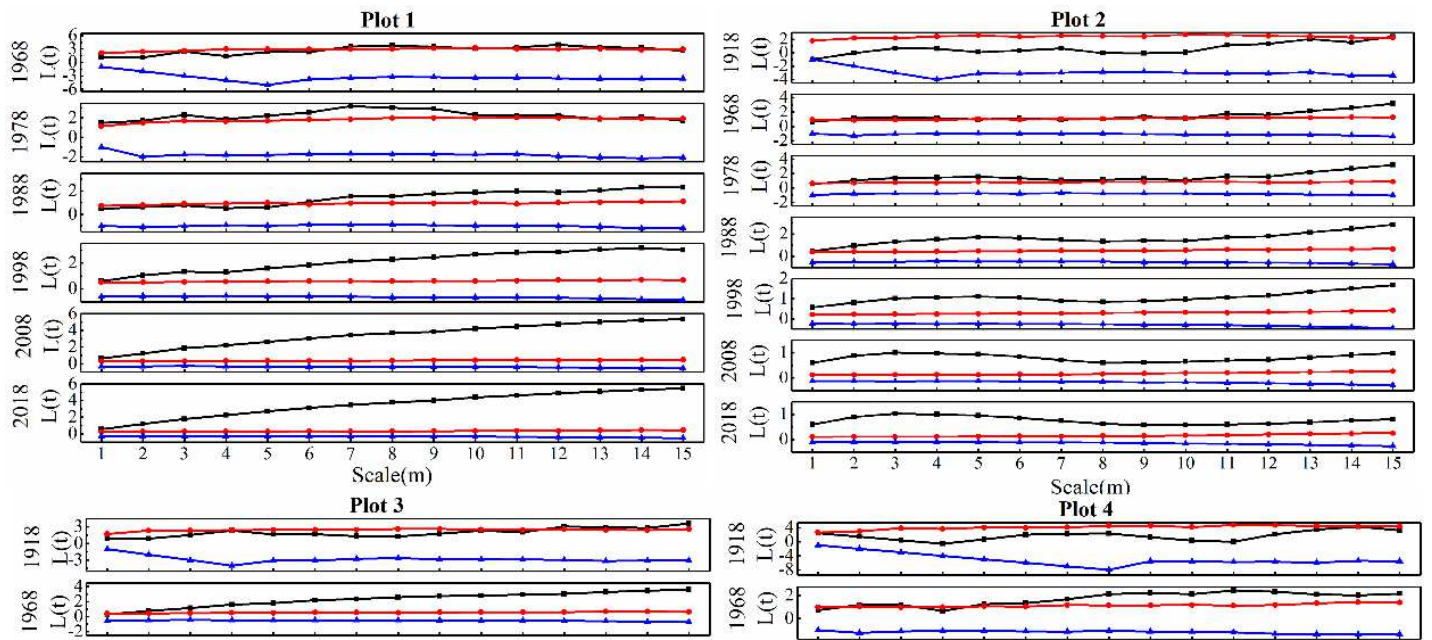

\& $\varepsilon_{0}^{2}$

$\stackrel{\circ}{\circ} \int_{-2}^{4} \Longrightarrow ?$

$\stackrel{S^{2}}{2}{ }^{2}$

$\stackrel{\circ}{9} \mathbb{2}_{1}^{2}$

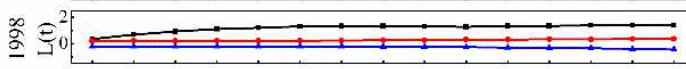

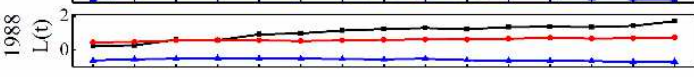

号 $\hat{y}^{1}: \div$

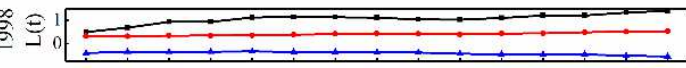

空 $\hat{y}^{1}$

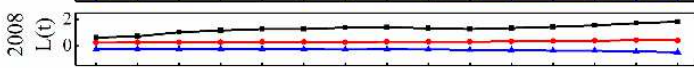

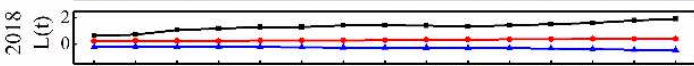
Scale $(\mathrm{m})$

$\infty \int_{-2}^{2}$

$\mathscr{O} \bigodot_{-1}^{1}$

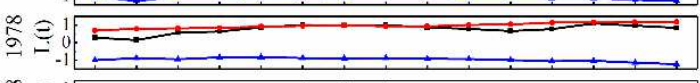

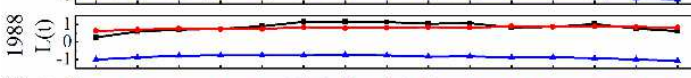

$\stackrel{2}{\infty} \bigodot_{0}^{1}$

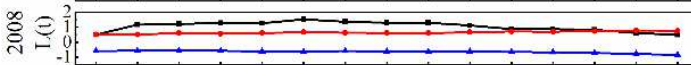

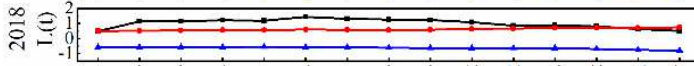

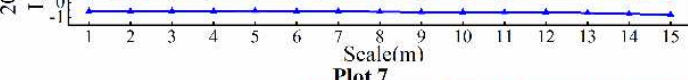

$\frac{\text { Plot } 7}{9} \int_{-2}^{2}$

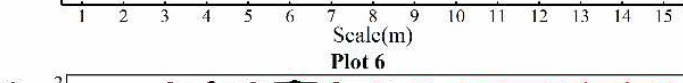

$\frac{100}{2} \varrho_{-2}^{2}$

o ${ }^{2} 02$

$\stackrel{2}{O}_{-2}^{2}$

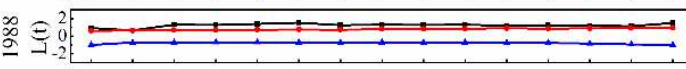

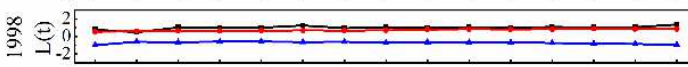

$\left.\overbrace{0}^{\infty}\right|_{-2} ^{2}=2$

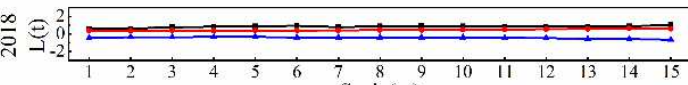
Scale $(\mathrm{m})$
Plot 8

$\approx \Xi_{-2}^{2}$

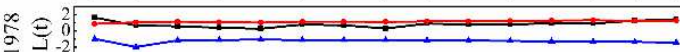

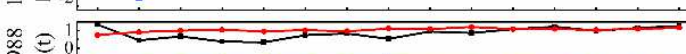

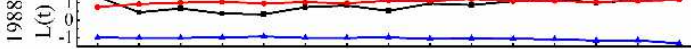

$\circ \int_{-1}^{1}$

$\infty$ 舟

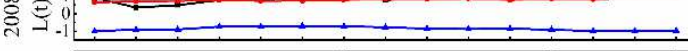

事

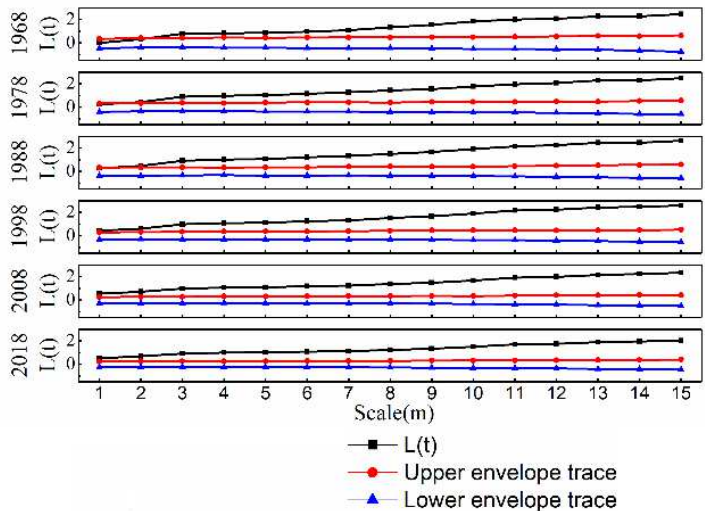

- Lower envelope trace

241 Figure 6. The change in point pattern (Graph of L(t) versus distance $(\mathrm{t})$ for trees at

242 each plot) at the lower tree line. The black line shows L $(\mathrm{t})$, and the red and blue lines 


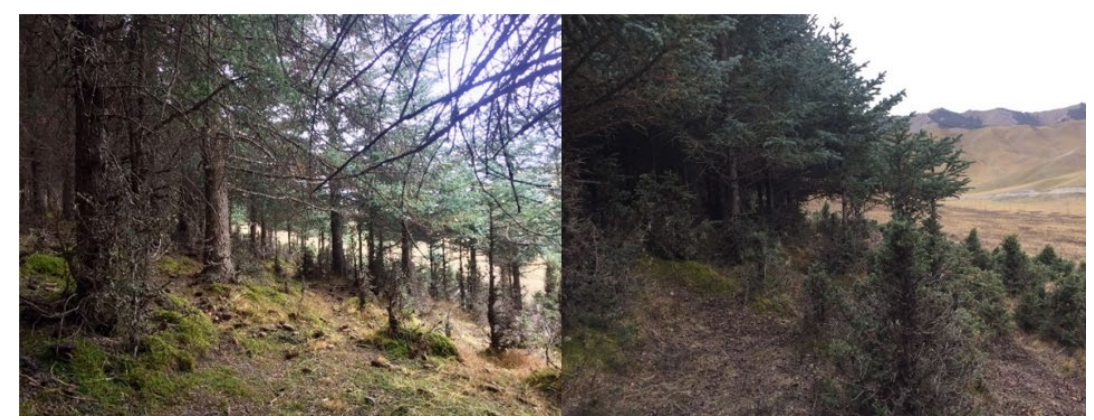

Figure 7. Layering of trees of different ages.

2463.4 Relationship between tree line changes and meteorological factors

We calculated climate trends at the Yeniugou weather station, and determined that

248 the temperature increased at a mean rate of $0.41{ }^{\circ} \mathrm{C}$ decade from 1968 to 2008 , and there

249 is a slight drop after 2008. The annual average temperature in the region increased by

250 a total of $2.00^{\circ} \mathrm{C}$ from 1968 to 1998 but decreased by a total of $0.49^{\circ} \mathrm{C}$ from 1998 to

251 2013. In general, the rate of temperature increase was lowest in autumn $\left(0.02^{\circ} \mathrm{C}\right.$ per

252 year) and highest in summer $\left(0.06^{\circ} \mathrm{C}\right.$ per year $)$ from 1968 to 2013 . Annual precipitation

253 increased with a mean rate of $0.82 \mathrm{~mm}$ per year. Spring precipitation decreased slightly

254 (by $0.13 \mathrm{~mm}$ per year), whereas summer precipitation increased significantly $(0.91 \mathrm{~mm}$

255 per year). Fall and winter precipitation changed little. Therefore, the change in annual

256 precipitation was mainly caused by increased summer precipitation.

258 line (Table 4) showed that the trend in temperature warming from 1968 to 2007 has

259 been weakening, especially in 1998-2007 (the increase in temperature was $<1{ }^{\circ} \mathrm{C}$ ),

260 while the lower tree line descent from 1968 to 2007 also slowed. There was a slight 
261 decrease in temperature after 2008, and the elevation of the lower tree line remained 262 unchanged.

263 The correlation between different meteorological factors and tree renewal rate 264 calculated for each plot is shown in Figure 8. The results show that the change in tree 265 recruitment was not significantly correlated with precipitation $(-0.023<\mathrm{r}<0.272,0.056<$ $266 \mathrm{P}<0.937)$ except with annual precipitation $(\mathrm{r}=0.299, \mathrm{P}=0.035)$. The regeneration rate of 267 trees at the lower tree line was highly correlated with the monthly average temperature 268 from June to July and September, the summer average temperature and the annual 269 average temperature. Also, regeneration rate of trees at the lower tree line was 270 correlated with monthly average temperature of February and August.

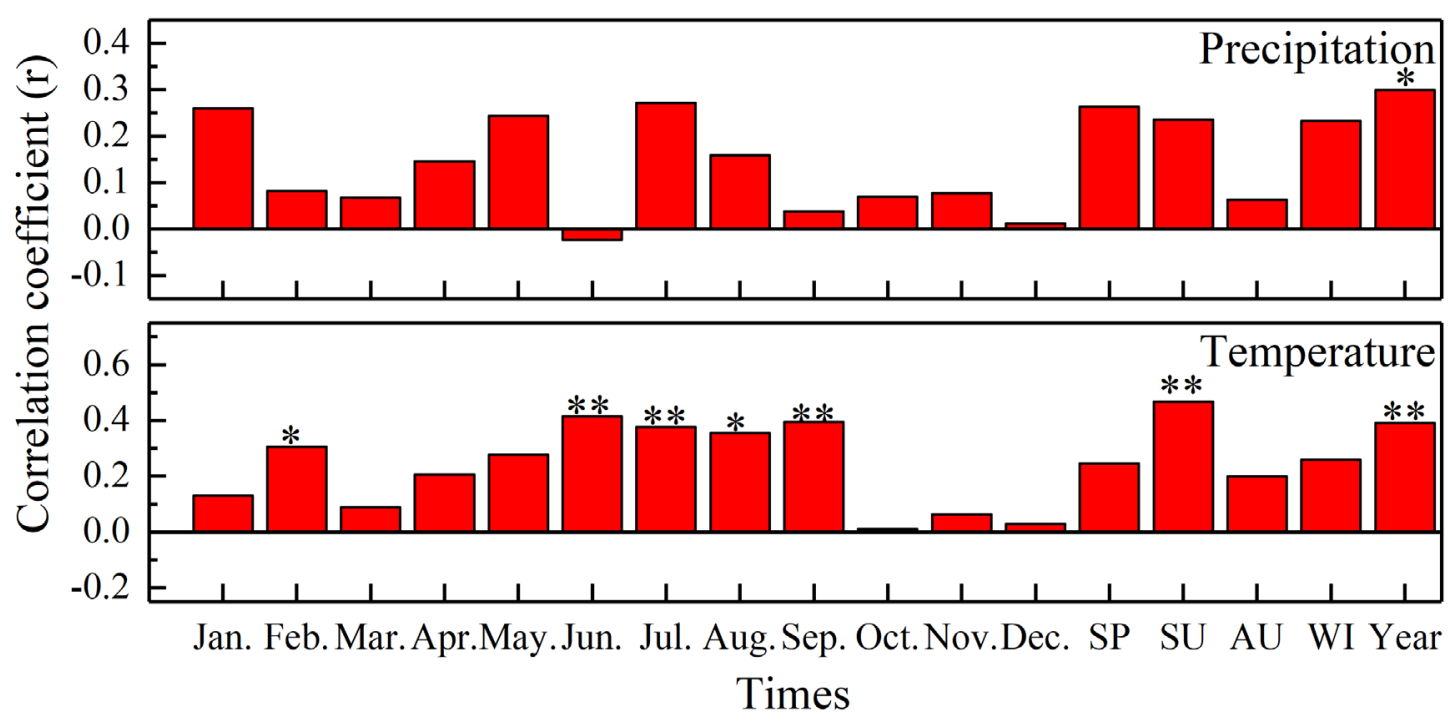

272 Figure 8. Pearson's correlation coefficients between the tree recruitment rate and

273 temperature, and precipitation. $(\mathrm{SP}=$ Spring, $\mathrm{SU}=$ Summer, $\mathrm{AU}=\mathrm{Autumn}, \mathrm{WI}=$ Winter,

$$
\text { * means } \mathrm{P}<0.05, * * \text { means } \mathrm{P}<0.01)
$$

\section{Discussion}



relationship with climate change. the Picea crassifolia Kom. tree line ecotone exhibiting a downward tendency to expand.

282 In a study of the upper tree line at high latitudes and altitudes, Harsch et al. (2009) 283 found that $52 \%$ of the mountain tree line positions have shifted upward [41]; an advance 284 of the tree line has been observed in Europe, North America, New Zealand, and in other 285 regions worldwide $[42,43]$. In some forests where the tree line did not expand upward 286 significantly such as in subalpine fir forests in Glacier National Park, USA, tree line 287 areas experienced a gradual alteration from tundra to forest [44]. At high altitudes and 288 latitudes, the tendency of tree line area to expand had been detected and attributed to 289 the warming temperature [45-47].

In the Qilian Mountains, vegetation cover of vegetation appears to have been 291 increasing during 1982-2014 [48]. Carbon mass of Picea crassifolia Kom. forest in the 292 Qilian Mountains has increased by $1.202 \mathrm{~kg} / \mathrm{m}^{2}$ from 1964 to 2013 [49]. One survey 293 showed that Picea crassifolia Kom. forest population density increased 23-fold at the 294 tree line, but the tree line position was not significantly altered during the past 100 years 295 [50]. Another survey indicated that the elevation of the upper tree line shifted upward 296 between 6.1 to $10.4 \mathrm{~m}$ from 1957 to 1980 , but showed no obvious change in 1980 to 
2972007 [30]. Further, the number, area, and concentration of forest patches have been

298 increasing from 1968 to 2017 in relatively flat and partly-sunny areas, but the rate of

299 area increase and ascent of the tree line slowed after 2008 [51]. Our research results are

300 similar to those from the Qilian Mountains; the lower tree line in the Qilian Mountains

301 has shifted down in the past 50 years, but the shift is not large, and the expansion rate

302 has begun to decline after 1998, with no change after 2008.

3034.2 Pattern characteristics of Picea crassifolia Kom. forest

304 In site survey, $78 \%$ of the trees were recruited after 1960 , therefore, most of the

305 trees were small [52]. With an increase in tree age, the landscape pattern gradually

306 changed from cluster to random distribution. The reason for this was that the young

307 trees assemble in the direction of a parent-tree seed propagation and in an environment

308 with less shade and rain; large trees were randomly distributed after the self-

309 organization process of competition and self-thinning [30, 53], which describes plant

310 mortality due to competition in crowded even-aged stands [54, 55]. The self-thinning

311 rule predicts that for a crowded even-aged plant population a log-log plot of average

312 plant mass versus plant density will reveal a "self-thinning" line with a slope of $-3 / 2$

$313[56,57]$. The major factor driving the self-thinning process is competition among plants

314 [58]. Meanwhile the landscape change form cluster to random with an increase in tree

315 age we observed was also consistent with one of the most important principles in plant

316 ecology, namely, the competition-density principle which states that for a given

317 dominant height or age, average tree size decreases as density increases due to 
318 competition for site resources such as light, water, nutrients and space [59].

3194.3 Meteorological factors

320 Meteorological factors affect the distribution of tree lines and tree regeneration

321 rates [3]. In our study, the regeneration rate of Picea crassifolia Kom. forest at the lower

322 tree line position was highly correlated with temperature, and moderately with annual

323 precipitation. The main meteorological factor that affects the distribution of the alpine

324 tree line in China is the temperature during the growing season, and mostly precipitation

325 affects the distribution of the tree line indirectly through temperature [60]. For Picea

326 crassifolia Kom. forests that grow in high-altitude areas with sufficient rainfall, June

327 temperatures control the melting of snow and ice, and July-August temperatures affect

328 radial growth [61], and average temperature in the wettest season (growth season) has

329 a significant effect on Picea crassifolia Kom. forests growth [17]. The expansion and

330 regeneration at the lower tree line is also limited by annual rainfall [14]. A study which

331 combined remote sensing and plot surveys in Picea crassifolia Kom. forests in Dayekou

332 watershed revealed that the upper tree line was distributed at the threshold of mean

333 annual air temperature at the upper elevation boundary of -2.59 to $-2.73^{\circ} \mathrm{C}$, while the

334 lower tree line was distributed at the threshold of mean annual precipitation of 378.1 to

$335372.3 \mathrm{~mm}[62]$.

336 5. Conclusions

337 We used site surveys to investigate the change of the Picea crassifolia Kom. lower

338 tree line position and landscape pattern in the Qilian Mountains. Our results showed 
339 that the lower tree line of Picea crassifolia Kom. forest had a descending trend from

340 1968-2008, and almost no change after that. Tree regeneration rates changes in lower

341 tree lines were highly correlated with temperature, and also related to annual

342 precipitation. In the past 50 years, the lower tree line of Picea crassifolia Kom. montane

343 forests in arid areas exhibited a downward trend under climatic conditions of higher

344 temperatures and increased precipitation. However, it is unclear whether the downward

345 trend of the lower forest line will stabilize or even reverse due to the weakening of

346 climate warming degree and warrants further investigation.

\section{Declarations}

348 Ethics approval and consent to participate: Not applicable.

349 Consent for publication: Not applicable.

350 Availability of data and materials: The datasets used and/or analysed during the

351 current study are available from the corresponding author on reasonable request.

352 Competing interests: The authors declare that they have no competing interests.

353 Funding: This research was funded by the $\mathrm{PhD}$ early development program of

354 Shangluo University (19SKY027), the National Key Research and Development

355 Program of China (No.2017YFC0504306), the Strategic Priority Research Program of

356 the Chinese Academy of Sciences (No.Y92C782001).

357 Authors' contributions: Z.H. and S.F. conceived and designed the experiments; S.F.

358 performed the experiments, analyzed the data and wrote the paper. All authors have

359 read and agreed to the published version of the manuscript. 
360 Acknowledgements: We are very grateful to Kathryn Piatek for her comments and

361 editorial assistance.

362 References:

363 1. Körner C (1998) A re-assessment of high elevation treeline positions and their 364 explanation. Oecologia.115(4):445-59.

365 2. Wieser G (2012) Lessons from the timberline ecotone in the Central Tyrolean Alps:

366 a review. Plant Ecology \& Diversity.5(1):127-39.

367 3. Hofgaard A, Dalen L, Hytteborn H (2009) Tree recruitment above the treeline and 368 potential for climate - driven treeline change. Journal of Vegetation 369 Science.20(6):1133-44.

370 4. Weltzin JF, McPherson GR (1995) Potential effects of climate change on lower 371 treelines in the southwestern United States. LF DeBano, GJ Gottfried, RH Hamre, CB

372 Edminster, PF Ffolliott, and A Ortega-Rubio, technical coordinators, Biodiversity and 373 management of the Madrean Archipelago: the sky islands of southwestern United States 374 and Northwestern Mexico USDA Forest Service General Technical Report RM$375 \quad 264.180-94$.

376 5. MacDonald GM, Velichko AA, Kremenetski CV, Andreev A (2000) Holocene 377 treeline history and climate change across northern Eurasia. Quaternary 378 Research.53:302-11.

379 6. Hofgaard A (1997) Inter-relationships between treeline position, species diversity, 380 land use and climate change in the central Scandes Mountains of Norway. Global 
Ecology and Biogeography Letters.419-29.

7. Vanneste T, Michelsen O, Graae BJ, Kyrkjeeide MO, Holien H, Hassel K, et al. (2017)

383 Impact of climate change on alpine vegetation of mountain summits in Norway.

384 Ecological Research.32(4):1-15.

385 8. Harsch MA, Hulme PE, McGlone MS, Duncan RP (2009) Are treelines advancing?

386 A global meta - analysis of treeline response to climate warming. Ecology 387 letters.12(10):1040-9.

388 9. Malanson GP, Resler LM, Bader MY, Holtmeier F-K, Butler DR, Weiss DJ, et al. 389 (2011) Mountain treelines: a roadmap for research orientation. Arctic, Antarctic, and 390 Alpine Research.43(2):167-77.

391 10. Smith WK, Germino MJ, Johnson DM, Reinhardt K (2009) The altitude of alpine 392 treeline: a bellwether of climate change effects. The Botanical Review.75(2):163-90.

393 11. Kullman L (2001) 20th century climate warming and tree-limit rise in the southern 394 Scandes of Sweden. Ambio: A journal of the Human Environment.30(2):72-80.

395 12. Gatti RC, Callaghan T, Velichevskaya A, Dudko A, Fabbio L, Battipaglia G, et al. 396 (2019) Accelerating upward treeline shift in the Altai Mountains under last-century 397 climate change. Scientific reports.9(1):1-13.

398 13. Liu LS, Shao XM, Liang EY (2006) Climate signals from tree ring chronologies of 399 the upper and lower treelines in the Dulan region of the northeastern Qinghai - Tibetan 400 Plateau. Journal of Integrative Plant Biology.48(3):278-85.

401 14. He Z, Du J, Chen L, Zhu X, Zhao M (2016) Review on Montane Forest Eco- 
402

403 404 405 406 407 408 treeline in the Swiss Alps. Ecology and evolution.7(19):7937-53. hydrology in Arid Area. ADVANCES IN EA R TH SCIENCE.31(10):1078-89. 2001-2012 Inspected with MODIS Time Series. Forests.9(2):91. Mountains. Sci Rep.7: 2245. Ecologica Sinica.29(5):278-85. Alpine forests. Global Change Biology.19(1):229-40. elevational gradient: climate or genetics? Oecologia.173(4):1587-600. 15. Lewińska KE, Ivits E, Schardt M, Zebisch M (2018) Drought Impact on Phenology and Green Biomass Production of Alpine Mountain Forest — Case Study of South Tyrol

16. Lin P, He Z, Du J, Chen L, Xi Z, Jing L (2017) Recent changes in daily climate extremes in an arid mountain region, a case study in northwestern China's Qilian

17. Xu Z, Zhao C, Feng Z (2009) A study of the impact of climate change on the potential distribution of Qinghai spruce (Picea crassifolia) in Qilian Mountains. Acta

18. Urza AK, Weisberg PJ, Dilts T (2020) Evidence of widespread topoclimatic limitation for lower treelines of the Intermountain West, USA. Ecological Applications. 19. Rigling A, Bigler C, Eilmann B, Feldmeyer - Christe E, Gimmi U, Ginzler C, et al. (2013) Driving factors of a vegetation shift from Scots pine to pubescent oak in dry

20. King GM, Gugerli F, Fonti P, Frank DC (2013) Tree growth response along an

21. Jochner M, Bugmann H, Nötzli M, Bigler C (2017) Among - tree variability and feedback effects result in different growth responses to climate change at the upper 22. Sun R, Zhang B (2013) Effect of Regional Topographic and Climatic Factors on 
23. Wieser G, Oberhuber W, Gruber A (2019) Effects of climate change at treeline:

426 Lessons from space-for-time studies, manipulative experiments, and long-term 427 observational records in the Central Austrian Alps. Forests.10(6):508.

428 24. Grace J, Berninger F, Nagy L (2002) Impacts of climate change on the tree line. 429 Annals of Botany.90(4):537-44.

431 Coupled ecohydrology and plant hydraulics modeling predicts ponderosa pine seedling 432 mortality and lower treeline in the US Northern Rocky Mountains. New 433 Phytologist.221(4):1814-30.

434 26. Herrero A, Rigling A, Zamora R (2013) Varying climate sensitivity at the dry 435 distribution edge of Pinus sylvestris and P. nigra. Forest Ecology and 436 Management.308:50-61.

437 27. Chang $X$, Zhao W, He Z (2014) Radial pattern of sap flow and response to 438 microclimate and soil moisture in Qinghai spruce (Picea crassifolia) in the upper Heihe 439 River Basin of arid northwestern China. Agricultural and Forest Meteorology.187:1444021.

441 28. Chang X, Zhao W, Liu H, Wei X, Liu B, He Z (2014) Qinghai spruce (Picea 442 crassifolia) forest transpiration and canopy conductance in the upper Heihe River Basin 443 of arid northwestern China. Agricultural and Forest Meteorology.198:209-20. 

plant communities, grazing impact and degradation status (Gansu province, NW China). Hacquetia.15(2):21-35. variability in the alpine treeline ecotone of the Qilian Mountains, northwestern China.

449 Forest Science.59(1):118-26.

451 of Qinghai spruce (Picea crassifolia) to environmental factors in the Qilian Mountains 452 of China. Dendrochronologia.44:76-83.

453 32. Lingnan Z, Shuangshuang L, Yixue H, Xiaomin Z, Xiaohong L (2020) Changes in 454 the radial growth of Picea crassifolia and its driving factors in the mid-western Qilian 455 Mountains, Northwest China since 1851 CE. Dendrochronologia.125707.

456 33. Liang E, Shao X, Eckstein D, Liu X (2010) Spatial variability of tree growth along 457 a latitudinal transect in the Qilian Mountains, northeastern Tibetan Plateau. Canadian 458 Journal of Forest Research.40(2):200-11.

459 34. He Z-b, Fang S, Chen L-f, Du J, Zhu X, Lin P-f (2018) Spatial patterns in natural 460 Picea crassifolia forests of northwestern China, as basis for close-to-nature forestry.

461 Journal of Mountain Science.15(9):1909-19.

462 35. Peng J, Gou X, Chen F, Li J, Liu P, Zhang Y, et al. (2008) Difference in tree growth 463 responses to climate at the upper treeline: Qilian juniper in the Anyemaqen Mountains. 464 Journal of integrative plant biology.50(8):982-90. 
36. Harcombe P (1987) Tree life tables. Bioscience.37(8):557-68.

37. Ripley BD (1977) Modelling Spatial Patterns. Journal of the Royal Statistical 467 Society.39(2):172-212.

38. Manly BF. Randomization, bootstrap and Monte Carlo methods in biology. CRC 469 press; 2006.

39. Dray S, Dufour A-B (2007) The ade4 package: implementing the duality diagram

471 for ecologists. Journal of statistical software.22(4):1-20.

40. Arbuckle JL (2010) IBM SPSS Amos 19 user's guide. Crawfordville, FL: Amos

Development Corporation.635.

41. Harsch MA, Hulme PE, Mcglone MS, Duncan RP (2009) Are treelines advancing?

A global meta-analysis of treeline response to climate warming. Ecology

Letters.12(10):1040.

42. Parmesan C, Yohe G (2003) A globally coherent fingerprint of climate change

478 impacts across natural systems. Nature.421(6918):37-42.

479 43. Pauli H, Gottfried M, Reiter K, Klettner C, Grabherr G (2007) Signals of range 480 expansions and contractions of vascular plants in the high Alps: observations (1994481 2004) at the GLORIA* master site Schrankogel, Tyrol, Austria. Global Change 482 Biology.13(1):147-56.

483 44. Klasner FL, Fagre DB (2002) A half century of change in alpine treeline patterns at 484 Glacier National Park, Montana, USA. Arctic, Antarctic, and Alpine Research.49-56. 485 45. de Wit HA, Bryn A, Hofgaard A, Karstensen J, Peters GP (2014) Climate warming 

uptake. Global Change Biology.20(7):2344.

46. Tague C, Heyn K, Christensen L (2009) Topographic controls on spatial patterns of conifer transpiration and net primary productivity under climate warming in mountain ecosystems. Ecohydrology.2(4):541-54.

47. Barros C, Guéguen M, Douzet R, Carboni M, Boulangeat I, Zimmermann NE, et al. (2017) Extreme climate events counteract the effects of climate and land-use changes in Alpine treelines. Journal of Applied Ecology.54(1):39.

48. Jia W, Chen J (2018) Variations of NDVI and Its Response to Climate Change in the Growing Season of Vegetation in Qilianshan Mountains from 1982 to

4962014 [in Chinese with English abstract]. Research of Soil and Water 497 Conservation.25(02):264-8.

498 49. Fang S, He Z, Du J, Chen L, Lin P, Zhao M (2018) Carbon Mass Change and Its 499 Drivers in a Boreal Coniferous Forest in the Qilian Mountains, China from 1964 to 500 2013. Forests.9(2):57.

501 50. Zhang L, Liu H (2012) Response of Picea crassifolia Population to Climate Change 502 at the Treeline Ecotones in Qilian Mountains[in Chinese with English abstract]. 503 SCIENTIA SILVAE SINICAE.(01):18-21.

504 51. Fang S, He Z (2020) Fifty Years of Change in a Coniferous Forest in the Qilian 505 Mountains, China-Advantages of High-Definition Remote Sensing. 506 Forests.11(11):1188. 
508 distribution pattern of Picea crassifolia in Pailugou basin, Qilian mountains [in

509 Chinese with English abstract]. Journal of Central South University of Forestry \& 510 Technology.38(11):75-80.

511 53. Kenkel N (1988) Pattern of self - thinning in jack pine: testing the random mortality 512 hypothesis. Ecology.69(4):1017-24.

513 54. Westoby M. The self-thinning rule. Advances in ecological research. Elsevier; 514 1984. p. 167-225.

515 55. Li B-L, Wu H-i, Zou G (2000) Self-thinning rule: a causal interpretation from 516 ecological field theory. Ecological Modelling.132(1-2):167-73.

517 56. Weller DE (1987) A reevaluation of the $-3 / 2$ power rule of plant self - thinning.

518 Ecological monographs.57(1):23-43.

519 57. Zeide B (1987) Analysis of the $3 / 2$ power law of self-thinning. Forest 520 Science.33(2):517-37.

521 58. Ma P, Han X-H, Lin Y, Moore J, Guo Y-X, Yue M (2019) Exploring the relative 522 importance of biotic and abiotic factors that alter the self-thinning rule: Insights from 523 individual-based modelling and machine-learning. Ecological Modelling.397:16-24.

524 59. Vospernik S, Sterba H (2015) Do competition-density rule and self-thinning rule 525 agree? Annals of Forest Science.72(3):379-90.

526 60. Wang X, Zhang L, Fang J (2004) Geographical Differences in Alpine Timberline 527 and Its Climatic Interpretation in China [in Chinese with English abstract] 
529 61. Zhao C, Nan Z, Cheng G, Zhang J, Feng Z (2006) GIS-assisted modelling of the 530 spatial distribution of Qinghai spruce ( Picea crassifolia ) in the Qilian Mountains, 531 northwestern China based on biophysical parameters. Ecological 532 Modelling.191(3):487-500.

533 62. Yang W, Y W, AA W, Z L, X T, Z H, et al. (2018) Influence of climatic and 534 geographic factors on the spatial distribution of Qinghai spruce forests in the dryland 535 Qilian Mountains of Northwest China. Science of the Total Environment.612:1007. 
Figures

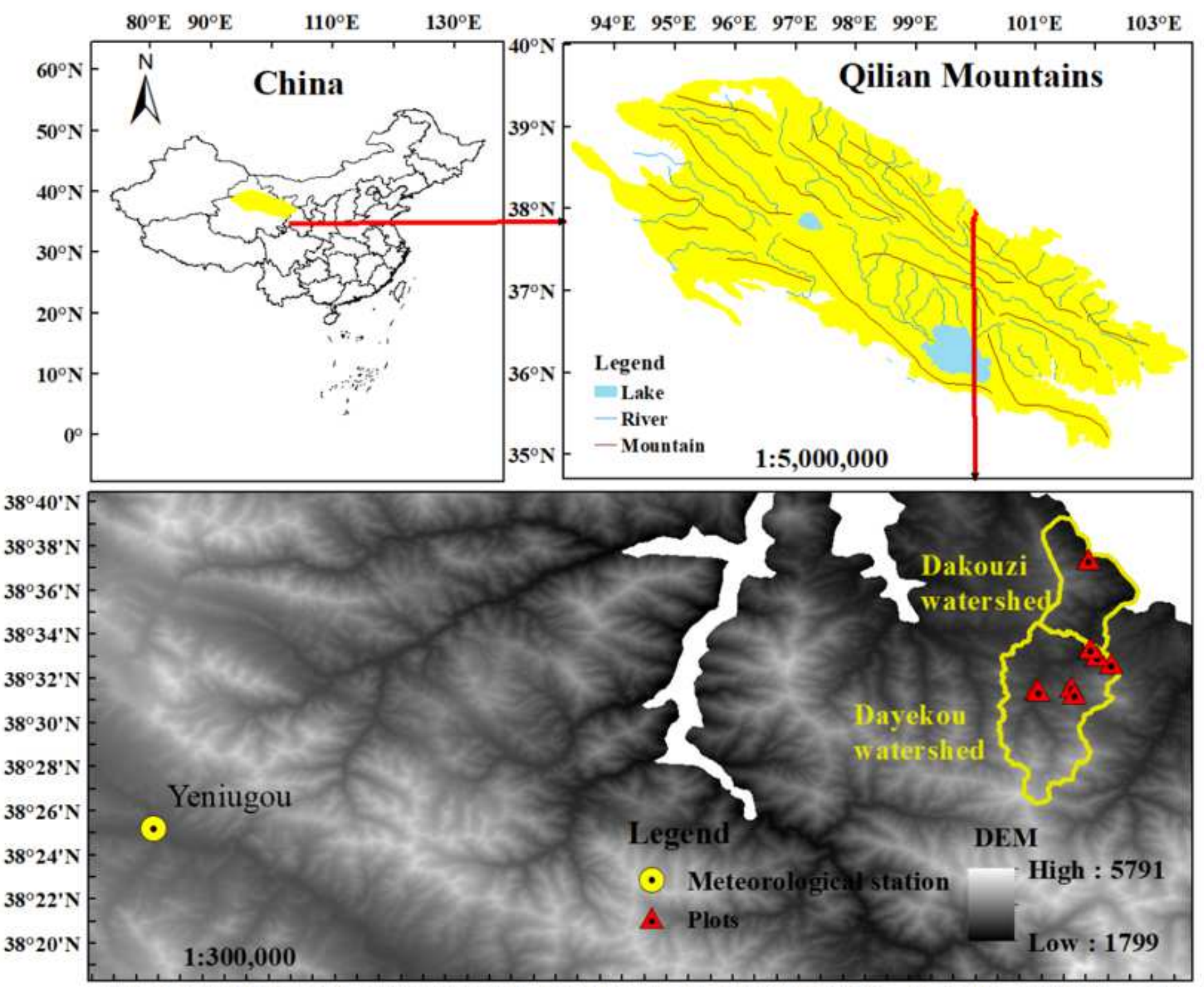

$99^{\circ} 34^{\prime} \mathrm{E} 99^{\circ} 38^{\prime} \mathrm{E} 99^{\circ} 42^{\prime} \mathrm{E} \quad 9^{\circ} 46^{\prime} \mathrm{E} \quad 9^{\circ} 50^{\prime} \mathrm{E} \quad 99^{\circ} 54^{\prime} \mathrm{E} \quad 99^{\circ} 58^{\prime} \mathrm{E} \quad 100^{\circ} 2^{\prime} \mathrm{E} \quad 100^{\circ} 6^{\prime} \mathrm{E} \quad 100^{\circ} 11 ' \mathrm{E} \quad 100^{\circ} 16^{\prime} \mathrm{E} \quad 100^{\circ} 21^{\prime} \mathrm{E}$

Figure 1

Study Area in the Qilian Mountains of northwestern China. 


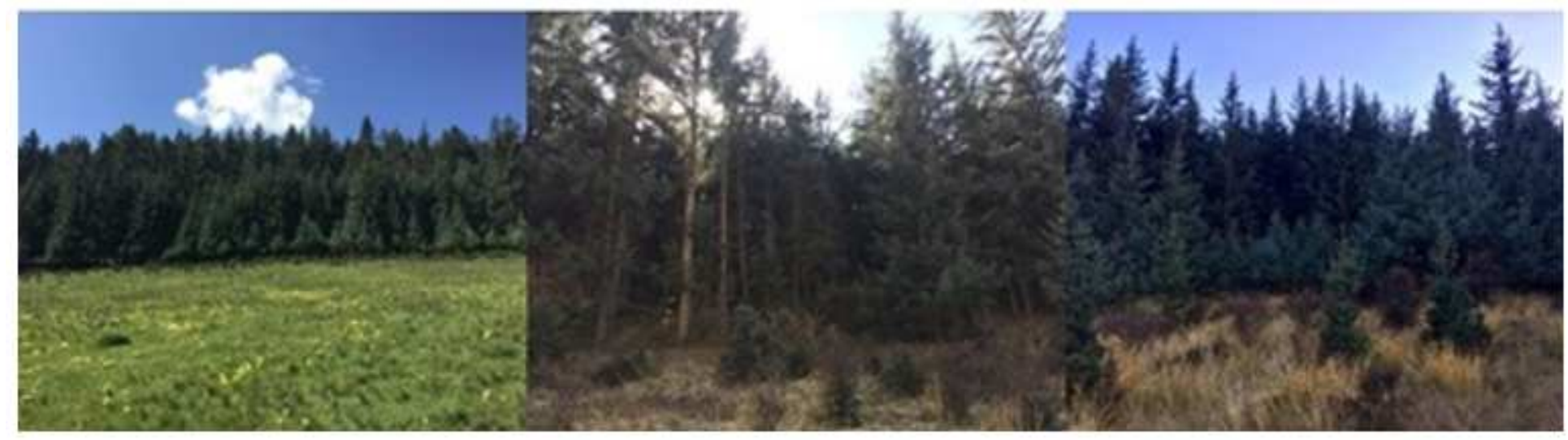

Figure 2

Examples of conditions in sample spots.

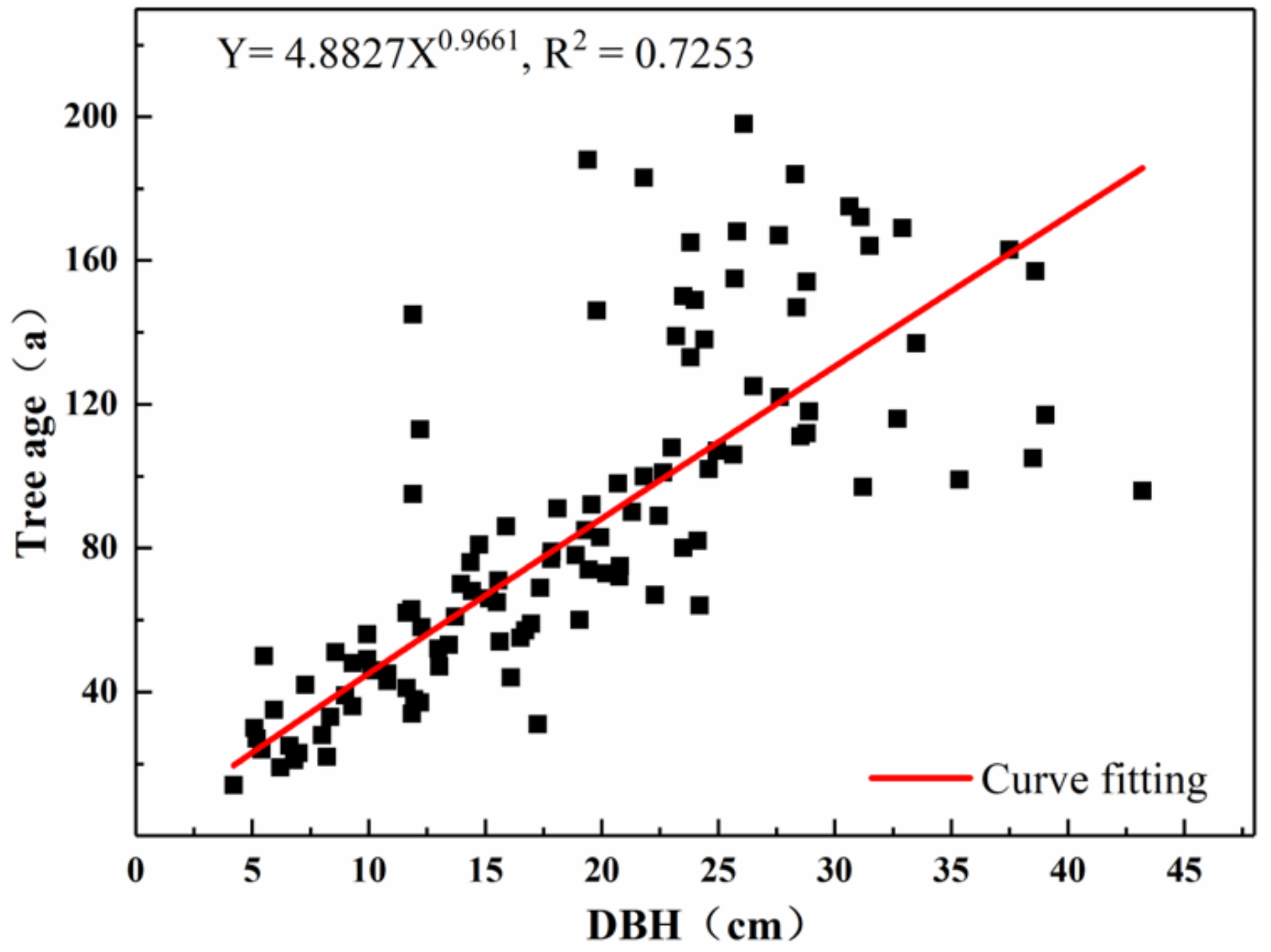

Figure 3

Functional relationship between diameter at breast height and age of trees in Guantai sampling. 


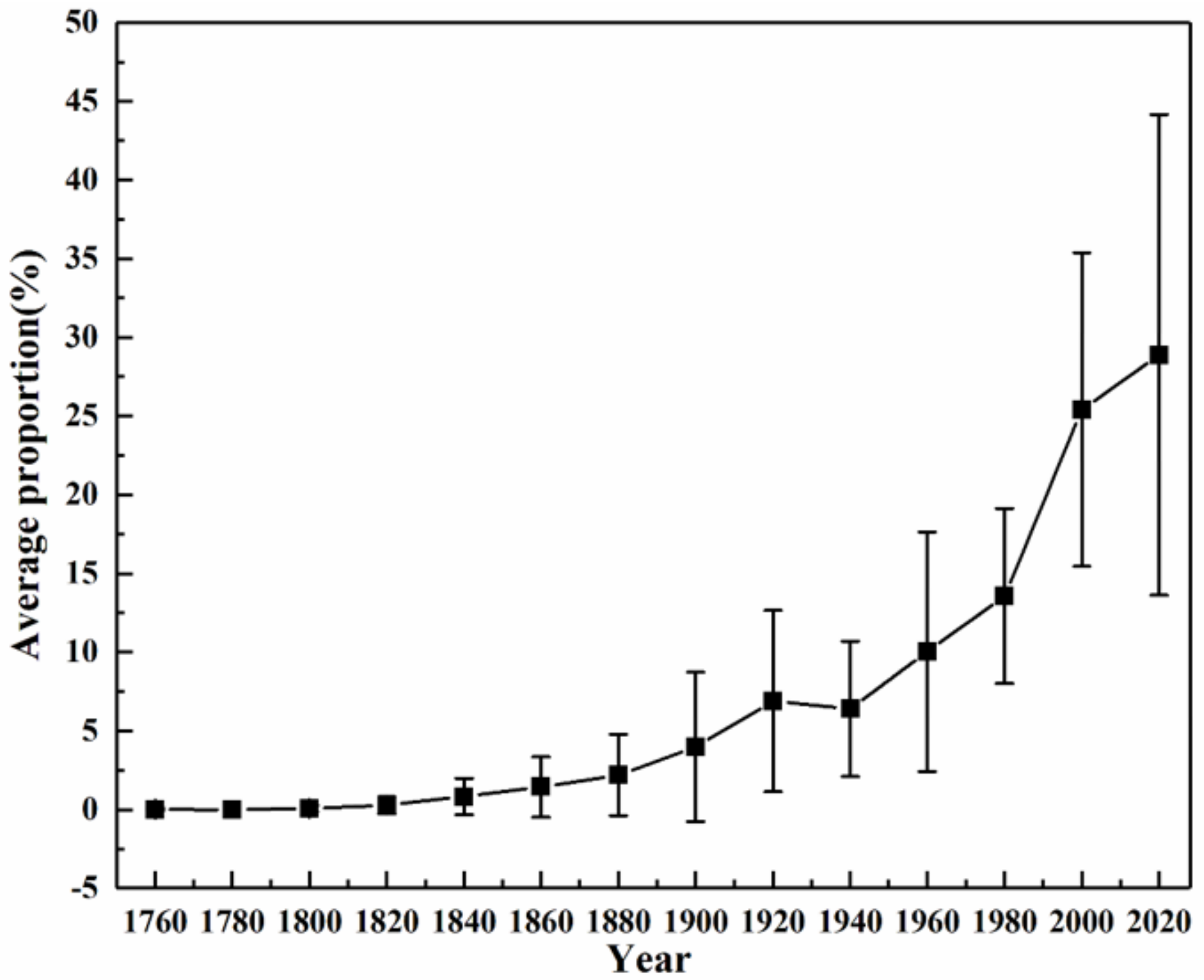

Figure 4

The age structure of the tree populations at the in the tree line ecotones plots at the lower tree line.
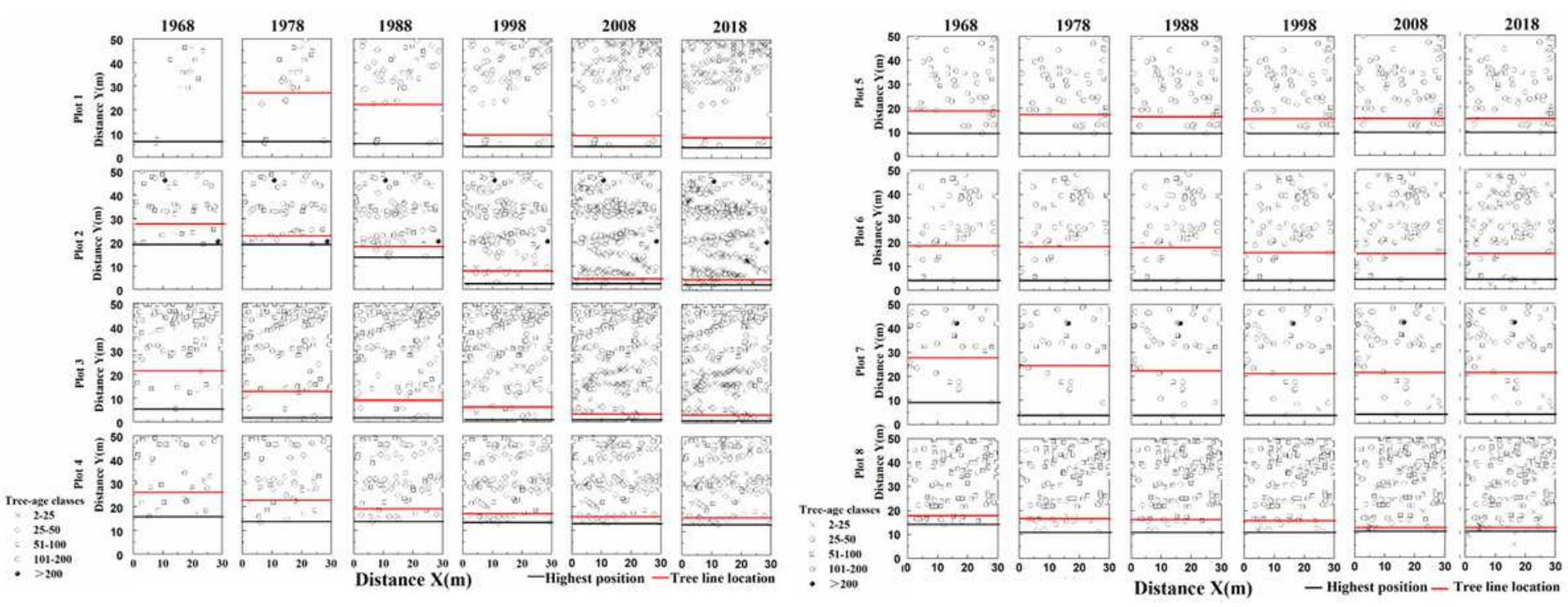


\section{Figure 5}

a. Changes in position of the lower tree line (1) (Distance $Y(m)$ is the distance along the slope direction and Distance $\mathrm{X}(\mathrm{m})$ is the distance spline perpendicular to the slope direction.) b. Changes in position of the lower tree line (2)
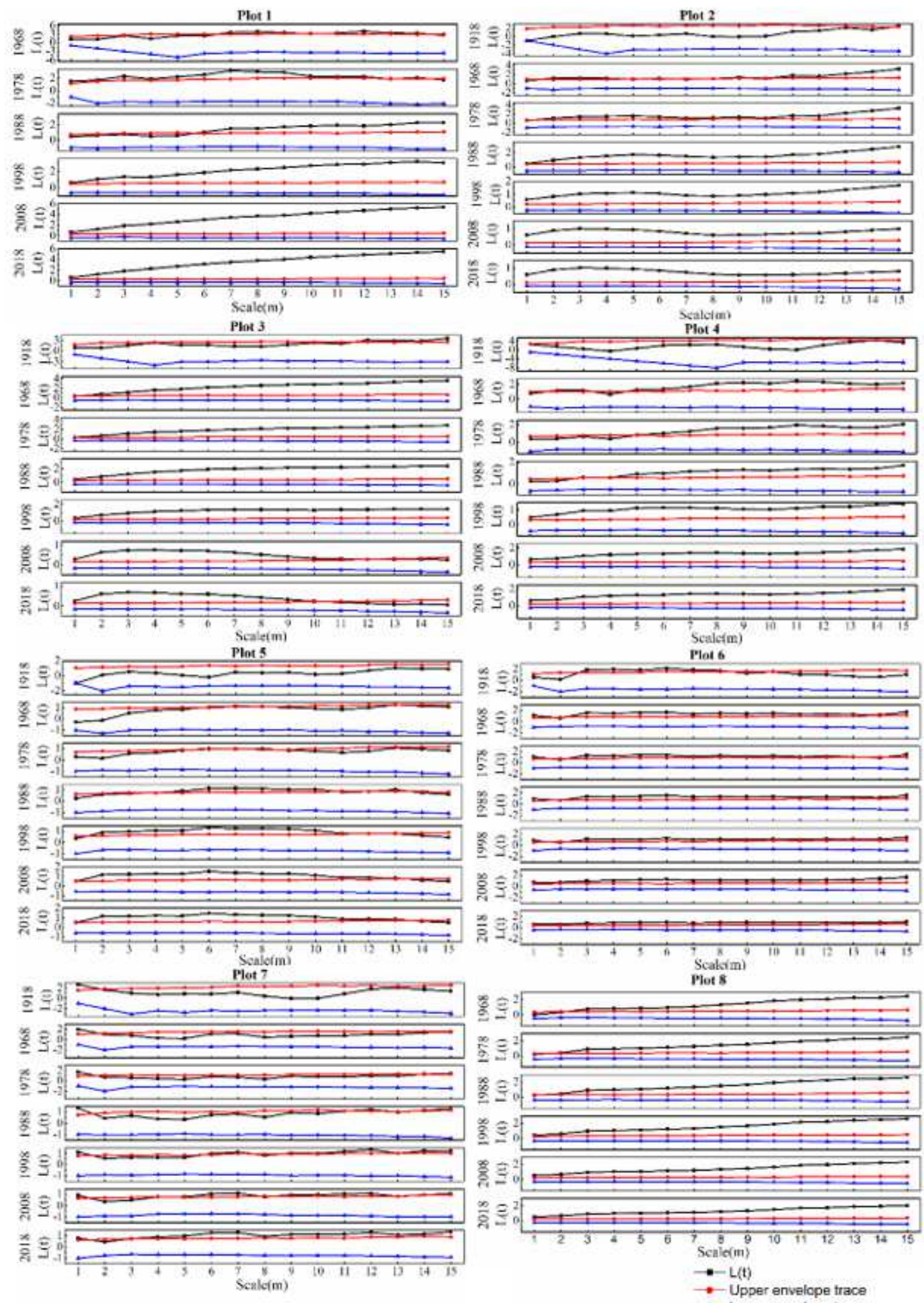

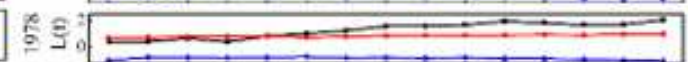

o 50

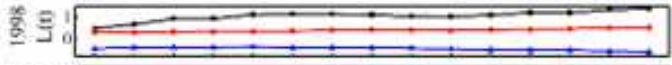

है요의

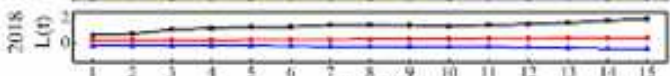

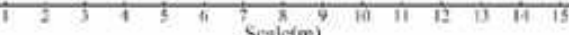

Plat 6

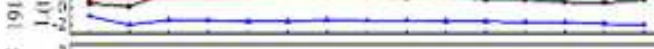

OE

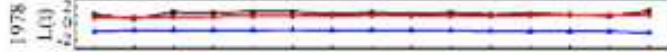

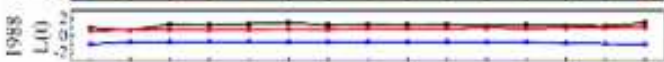

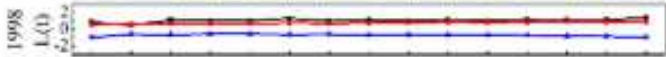

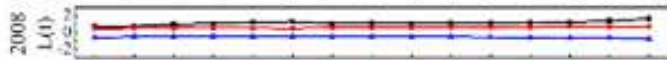

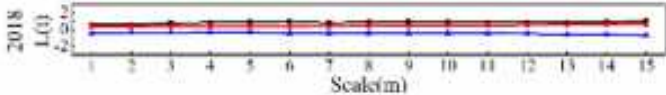
Plet 8

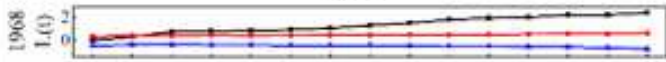

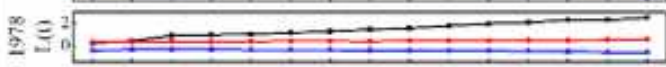

\%을 of

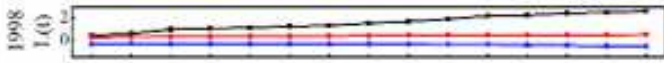

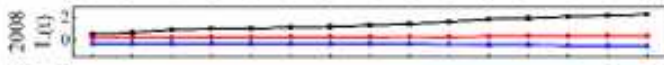

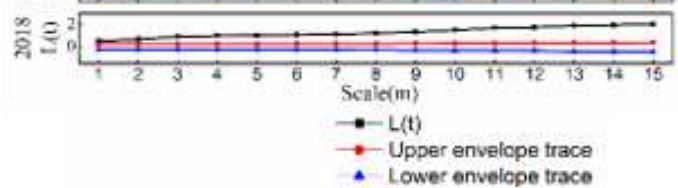

Figure 6 
The change in point pattern (Graph of $L(t)$ versus distance $(t)$ for trees at each plot) at the lower tree line. The black line shows $L(t)$, and the red and blue lines show the $99 \%$ confidence envelope for a random distribution.

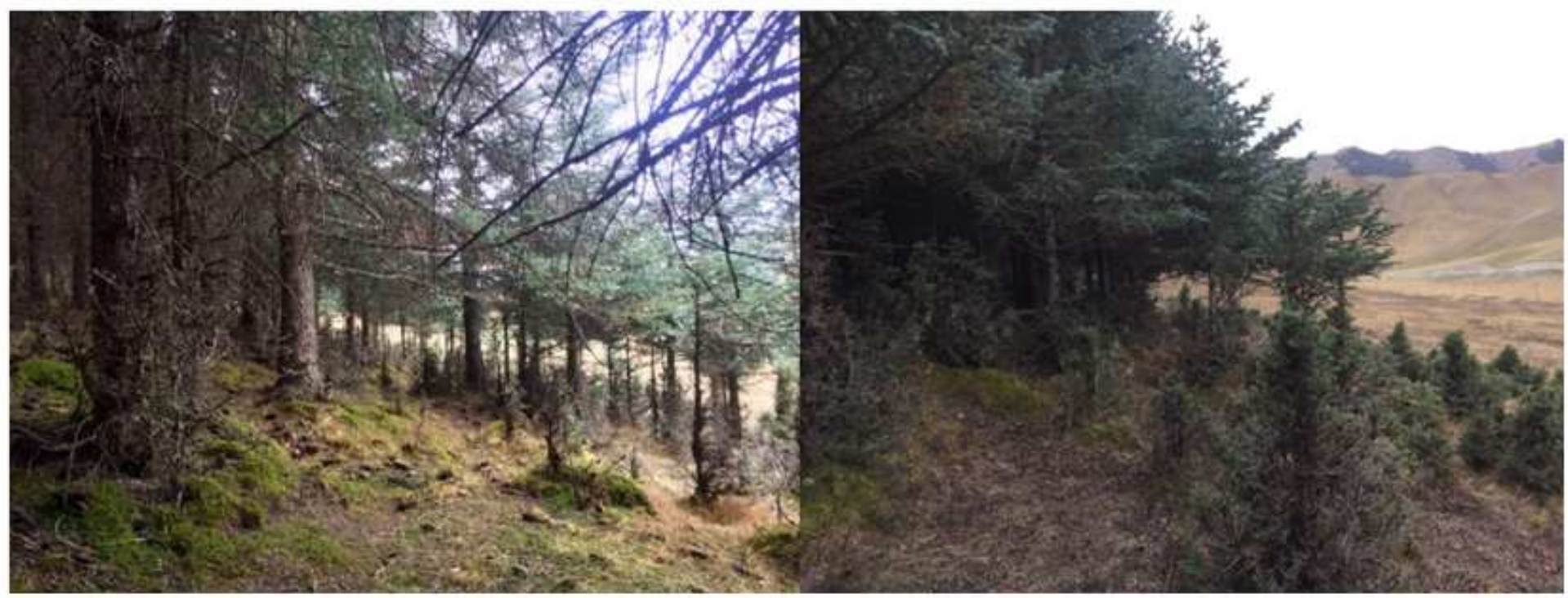

Figure 7

Layering of trees of different ages.

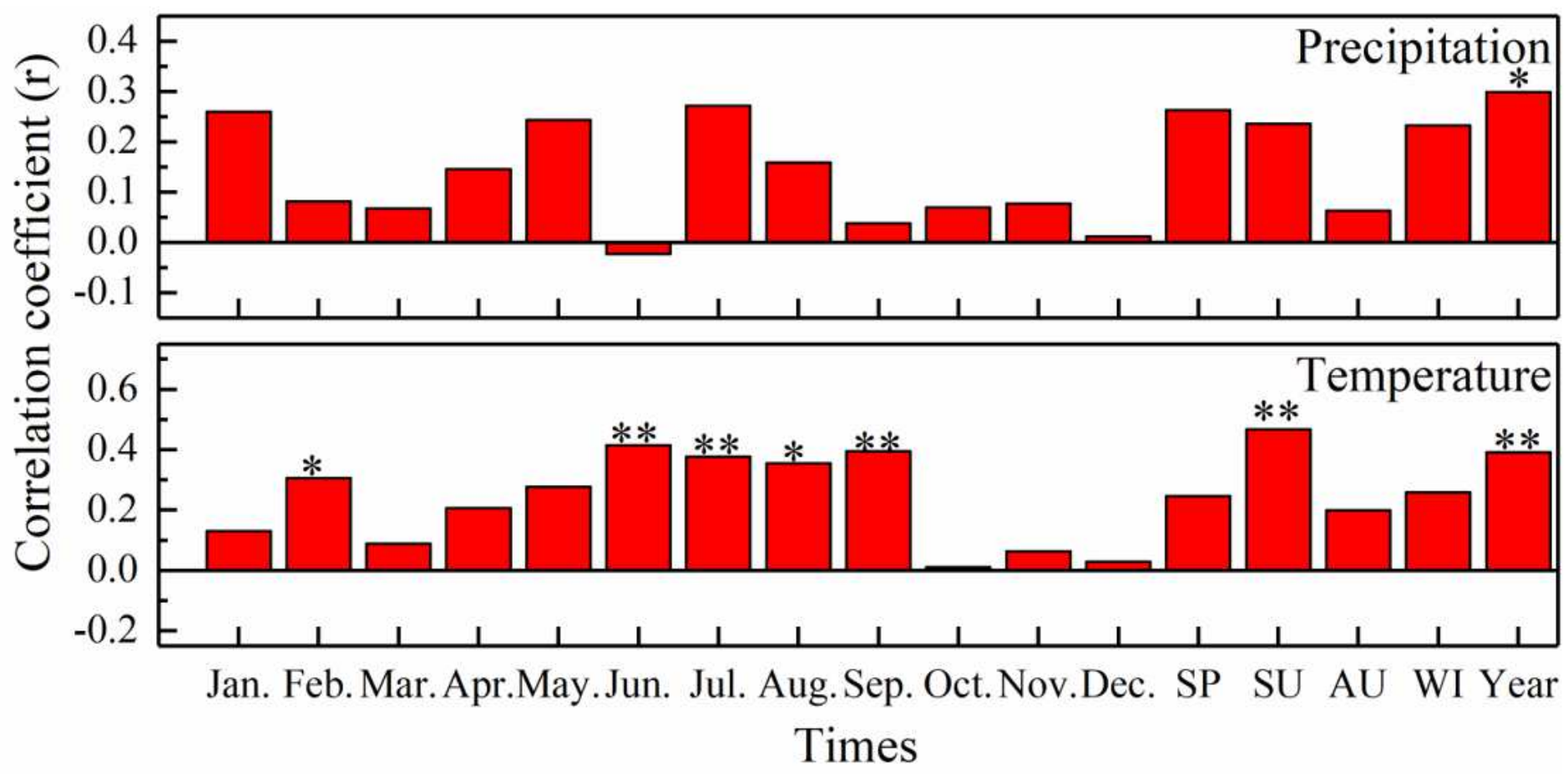

Figure 8

Pearson's correlation coefficients between the tree recruitment rate and temperature, and precipitation. $(\mathrm{SP}=$ Spring, $\mathrm{SU}=\mathrm{Summer}, \mathrm{AU}=$ Autumn, $\mathrm{WI}=$ Winter, * means $\mathrm{P} \otimes 0.05$, ** means $\mathrm{P} \bowtie 0.01)$ 